\title{
Antibiotic Utilization Pattern in Surgery and Pediatric, Bhagwan Mahaveer Jain Hospital, Bangalore, India
}

\author{
Mahdieh Soleimani *, Shivah Karamian \\ Doctor of pharmacy, Department of pharmacy practice, Aditya Bangalore Institute of Pharmacy Education and \\ Research, Bangalore, India \\ Corresponding author: Mahdieh Soleimani
}

\begin{abstract}
Objective: To assess antibiotic utilization pattern in surgery and pediatric and to explore reasons for the nonadherence.

Methods: A prospective clinical record review was done on 180 patients admitted in the Medicine, Surgery, and Paediatrics. The antibiotic prescription will be assessed whether it is according to hospital antibiotic policy and in case of violation the reason for it will be noted down. The incidence and cause for the nosocomial infection will be noted down. Apart from these antibiotic categories, cost of antibiotic therapy from medical bills and the cost for the antibiotics will be calculated.

Results: In our study population out of 180 patients 110 were male and 70 were female and in paediatric population $16 \%$ were male and $13.5 \%$. In surgery department highest number i.e. $12.5 \%$ male and $9.5 \%$ females are in the age group 31-40 years. 2\% males and 2.5\% females were in the age Group of 81-90. Various classes of antibiotics like penicillin's, macrolides, cephalosporin's and fluoroquinolones were prescribed. of which 13\% males, 7\% females were prescribed with penicillin's which were highest among monotherapy. Among combination therapy $14 \%$ of males were prescribed and $7 \%$ females with penicillin which were highest. There were various combination drugs prescribed which are specific to the disease out of which ampicillin+gentamicin+metronidazole (5\%) and ampicillin+gentamicin+cefotaxime +amikacin (5\%).

Conclusion: In appropriate use of antibiotics is detected due to lack of culture sensitivity test which has to make mandatory in the hospital before antibiotic prescription. Less cost effective antibiotic treatment should be prescribed. Polypharmacy was seen in a large extent were patients were put on 4-5 antibiotics which has to be avoided by using broad spectrum antibiotics and fixed dose antibiotics suitably. The drug interactions with antibiotics should be also minimized.
\end{abstract}

Keywords: antibiotic utilization, pattern in surgery, pattern in paediatrics.

\section{INTRODUCTION}

Antibiotics are among the most frequently prescribed drugs worldwide. According to results of studies carried out in European countries and the United States, 23-38\% of in-patients are given some kind of systemic antibiotic treatment .[2] Antibiotics take the lead among most commonly used drugs in Turkey and account for $20 \%$ of the drug market. [2] Unfortunately, 20-50\% of antibiotic treatment is used irrationally. The fact that one of the most important causes of acquiring resistance is the lack of rational antibiotic use has been reported in many studies and has taken its place in the literature as evidence. Inappropriate use of antibiotics leads to some undesired effects such as an increase in mortality and morbidity, drug toxicity, extended periods of hospitalization, and an increase in expenditures. [13]

Antibiotics are powerful and effective drugs in the fight against infectious diseases caused by bacteria, and have saved millions of lives since their first appearance about50 years ago. Rational use of antibiotics is extremely important as injudicious use can adversely affect the patient, cause emergence of antibiotic resistance and increase the cost. $[10,11]$ As per the World Health Organization, rational use of drugs requires that patients receive medications appropriate to their clinical needs, in doses that meet their own individual requirements for an adequate period of time, and at the lowest cost to them and their community ( WHO,1987). The use of antibiotic prophylaxis has been shown to prevent post-surgical wound infection. When employed rationally, significant reduction in the mortality and morbidity and saving in resources can be achieved. [8, 9]

Antibiotics are the sub stanceswhich selectively suppress the growth of or kill other microorganisms at very low concentration. This definition excludes other natural substances which also inhibit microorganism but are produced by microbes but are needed in higher concentration. [6] Especially in intensive care and surgical department antibiotics is the most frequently prescribed drugs. To increase quality of care, infection control and 
cost containment certain programs designed to encourage appropriate antibiotic prescriptions in health institutions. [7] Antibiotics are one of the pillars of modern medical care and play a major role both in the prophylaxis and treatment of infectious diseases. The issues of their availability, selection, and proper use are of critical importance to the global community. [15] As the use of antibiotics to prevent infections at the surgical site is known as the surgical antibiotic prophylaxis. It is an effective management strategy for reducing postoperative infections, provided that appropriate antibiotics are given at the correct time for appropriate durations and for appropriate surgical procedures. [16]

Surgical site infection (SSI) continues to be the most common complication following surgical procedures. Surgical site infections (SSIs) are not an extinct entity; they account for 14-16\% of the estimated 2 million Nosocomial infections affecting hospitalised patients in the United States.[14,4,5] Internationally, the frequency of SSI is difficult to monitor because criteria for diagnosis might not be standardised.1 A survey sponsored by the WHO demonstrated a prevalence of Nosocomial infections varying from 3 to $21 \%$, with wound infections accounting for 5-34\% of the total.1,4 The 2002 survey report by the Nosocomial Infection National Surveillance Service (NINSS), indicates that the incidence of hospital acquired infection related to surgical wounds in the United Kingdom is as high as10\% and costs the National Health Service in the United Kingdom approximately 1 billion pounds (1.8 billion dollars) annually.[14]

\section{Study design:}

\section{MATERIALS AND METHODS}

This is an observational study in inpatient department at a tertiary care hospital. Bhagwan Mahaveer Jain Hospital (BMJH).

\section{Source of data and Materials:}

- Inpatient case sheets

- Inpatient medication charts

- Nurse notes

- Physician notes

- Laboratory investigation charts

- CIMS

- Patients Interview

\section{Inclusive Criteria:}

All patients of either sex aging above 18 years of age, suffering from infective illness admitted under surgery and pediatrics department at Bhagwan Mahaveer Jain Hospital. Bangalore, India

\section{Exclusion Criteria:}

- Infective diseases caused by viruses, fungi, parasites.

- Pregnant women suffering from infective illness.

- Out patients

- Patients not receiving antibiotic

A hospital based study was conducted for a period of 6 months in inpatient paediatric and surgery at Bhagwan Mahaveer Jain Hospital (BMJH), Bangalore, India. A total of 180 inpatients were included in this study. Prescriptions and treatment chart of inpatients were reviewed for prescribed patterns of proton pump antibiotics. The hospital policy, therapeutic guidelines, Micromedex, Medscape and references books will be used as tools to review the prescription and case chart. The admission register is reviewed for prescription of any antibiotics. The case sheet, treatment chart, physician notes will be subjected for capturing any information related to the study.

All medically relevant information was noted in a predefined data collection form. Alternatively, these case charts were reviewed for prescription of antibiotics. The demographic data and the detailed history of patient regarding past, present, family, personal and drug history was taken. The other details like the present diagnosis, reason for the present admission, any investigations done to confirm the diagnosis were also noted.

Patients of both genders who were admitted into the inpatient wards in the Hospital, of all the age group were included in the study. The detailed information such as brand name, dosage, frequency, route, indication and any other relevant information will be retrieved and entered into the data collection form. The patients who have renal impairment, liver impairment and geriatric patients also taken. Also found drug interactions of antibiotics and drug selection, dosage forms, route, frequency, indication of antibiotics was also studied.

Rationality of antibiotic prescription were assessed by prescribing indicators like total number of drug prescribed; average number of drug per prescription, percentage of antibiotic prescribed, number of antibiotic used as mono therapy and in combination were recorded. The antibiotic prescriptions were assessed whether it 
Antibiotic Utilization Pattern in Surgery and Pediatric, Bhagwan Mahaveer Jain Hospital, ..

is according to hospital antibiotic policy and in case of violation the reason for it will be noted down. The incidence and cause for the nosocomial infection were noted down. Apart from these antibiotic categories, cost of antibiotic therapy from medical bills and the cost for the antibiotics will be calculated.

\section{RESULTS AND DISCUSSION}

In our study population out of 180 patients 110 were male and 70 were female and in paediatric population $16 \%$ were male and $13.5 \%$. In surgery department highest number i.e. $12.5 \%$ male and $9.5 \%$ females are in the age group 31-40 years. $2 \%$ males and $2.5 \%$ females were in the age Group of 81-90.table 1

Table 1: To Study Patient Distribution Based On Diagnosis

\begin{tabular}{|c|c|c|c|c|c|c|c|c|c|}
\hline \multirow{2}{*}{$\begin{array}{l}\text { System organ } \\
\text { classification }\end{array}$} & \multirow[t]{2}{*}{ Antibiotic indication } & \multicolumn{4}{|c|}{ gender } & \multicolumn{4}{|c|}{ Total } \\
\hline & & male & $(\%)$ & female & $(\%)$ & male & $(\%)$ & Female & $(\%)$ \\
\hline GIT & $\begin{array}{c}\text { Abdominal pain } \\
\text { ileostomy } \\
\text { Oesophagus } \\
\text { postchema } \\
\text { intestinal obstruction }\end{array}$ & $\begin{array}{l}4 \\
2 \\
1 \\
3\end{array}$ & $\begin{array}{l}(2) \\
(1) \\
(0.5) \\
(1.5)\end{array}$ & 2 & $\begin{array}{l}(1) \\
(0.5)\end{array}$ & 10 & $(5)$ & 4 & (2) \\
\hline APPENDIX & appendicitis & 12 & $(6)$ & 6 & (3) & 12 & $(6)$ & 6 & (3) \\
\hline PANCREAS & $\begin{array}{l}\text { Pancreatitis } \\
\text { cholecystitis }\end{array}$ & $\begin{array}{l}3 \\
2 \\
\end{array}$ & $\begin{array}{l}(1.5) \\
(1)\end{array}$ & $\begin{array}{l}8 \\
4 \\
\end{array}$ & $\begin{array}{l}(4) \\
(2)\end{array}$ & 5 & $(2.5)$ & 12 & (6) \\
\hline KIDNEY & $\begin{array}{c}\text { Chronic kidney } \\
\text { disease } \\
\text { nephrectomy }\end{array}$ & $\begin{array}{l}2 \\
2\end{array}$ & $\begin{array}{l}(1) \\
(1)\end{array}$ & $\begin{array}{l}4 \\
1\end{array}$ & $\begin{array}{l}(2) \\
(0.5)\end{array}$ & 4 & (2) & 5 & $(2.5)$ \\
\hline pulmonary & $\begin{array}{c}\text { Pneumonia } \\
\text { Respiratory tract } \\
\text { infection } \\
\text { tuberculosis } \\
\end{array}$ & $\begin{array}{c}18 \\
9 \\
5 \\
\end{array}$ & $\begin{array}{c}(9) \\
(4.5) \\
(2.5) \\
\end{array}$ & $\begin{array}{l}7 \\
2 \\
2\end{array}$ & $\begin{array}{l}(3.5) \\
(1) \\
(1)\end{array}$ & 32 & (16) & 11 & $(5.5)$ \\
\hline $\mathrm{CNS}$ & $\begin{array}{c}\text { Meningitis } \\
\text { septic shock } \\
\text { Cerebrovascular } \\
\text { disease }\end{array}$ & 1 & $(0.5)$ & $\begin{array}{l}2 \\
1 \\
1\end{array}$ & $\begin{array}{l}(1) \\
(0.5) \\
(0.5)\end{array}$ & 1 & $(0.5)$ & 4 & (2) \\
\hline CVS & $\begin{array}{c}\text { Coronary artery } \\
\text { disease } \\
\text { Myocardial } \\
\text { infarction } \\
\end{array}$ & $\begin{array}{l}4 \\
2\end{array}$ & $\begin{array}{l}(2) \\
(1)\end{array}$ & $\begin{array}{l}6 \\
2\end{array}$ & $\begin{array}{l}\text { (3) } \\
(1)\end{array}$ & 6 & (3) & 8 & (4) \\
\hline ENT & Nasal septal disease & & & & & & & 1 & $(0.5)$ \\
\hline Bone & $\begin{array}{l}\text { Pain in joints, } \\
\text { surgery, } \\
\text { fracture }\end{array}$ & $\begin{array}{l}1 \\
2 \\
1 \\
\end{array}$ & $\begin{array}{l}(0.5) \\
(1) \\
(0.5) \\
\end{array}$ & 1 & $(0.5)$ & 4 & (2) & 1 & $(0.5)$ \\
\hline Liver & $\begin{array}{l}\text { Fatty liver, } \\
\text { liver abscess }\end{array}$ & $\begin{array}{l}14 \\
12\end{array}$ & $\begin{array}{l}(7) \\
(6)\end{array}$ & & & 26 & (13) & 6 & (3) \\
\hline genitourinary & $\begin{array}{l}\text { Urinary tract infection } \\
\text { Uretic calculi }\end{array}$ & $\begin{array}{l}1 \\
1 \\
\end{array}$ & $\begin{array}{l}(0.5) \\
(0.5) \\
\end{array}$ & $\begin{array}{l}6 \\
2 \\
\end{array}$ & $\begin{array}{l}(3) \\
(1) \\
\end{array}$ & 2 & (1) & 8 & (4) \\
\hline Spleen & inflammation & & & & & 5 & $(2.5)$ & 1 & $(0.5)$ \\
\hline Paratoid & infection & & & & & 1 & $(0.5)$ & & \\
\hline palate & infection & & & & & & & 1 & $(0.5)$ \\
\hline fever & & 4 & $(2)$ & 3 & $(1.5)$ & 4 & $(2)$ & 3 & $(1.5)$ \\
\hline dengue & Decrease in platelets & 9 & $(4.5)$ & 5 & $(2.5)$ & 9 & $(4.5)$ & 5 & $(2.5)$ \\
\hline
\end{tabular}

In our study various class of antibiotics like penicillin's, macrolides, cephalosporins and fluoroquinolones were prescribed. Out of which $13 \%$ males, $7 \%$ females were prescribed with penicillin's which were highest among monotherapy. Among combination therapy $14 \%$ of males were prescribed and $7 \%$ females with penicillin are which were highest. There were various combination drugs prescribed which are specific to the disease out of which ampicillin + gentamicin + metronidazole $(5 \%)$ and ampicillin + gentamicin+cefotaxime + amikacin. (5\%) 
Table 2: Drug interactions in our study population

\begin{tabular}{|c|c|c|c|c|c|c|c|}
\hline Interacting drug/object drug & Effect of interaction & Male & $(\%)$ & Female & $(\%)$ & Total & $(\%)$ \\
\hline \multicolumn{8}{|l|}{ major } \\
\hline domperidone+azathioprine & Qt prolongation & 8 & $(5.4)$ & 2 & $(1.3)$ & 10 & (5) \\
\hline domperidone+ondansetron & Qt prolongation & 1 & $(0.7)$ & & $(0.0)$ & 1 & $(0.5)$ \\
\hline metronidazole+domperidone & Qt prolongation & 9 & $(6.0)$ & 8 & $(5.4)$ & 17 & $(8.5)$ \\
\hline ciprofloxacini+ondansetron & Qt prolongation & 11 & (7.4) & 2 & $(1.3)$ & 13 & $(6.5)$ \\
\hline ciprofloxacin+metronidazole & Qt prolongation & 11 & $(7.4)$ & 12 & $(8.1)$ & 23 & $(11.5)$ \\
\hline fluconazole+metronidazole & Qt prolongation & 1 & $(0.7)$ & 1 & $(0.7)$ & 2 & $(1)$ \\
\hline metronidazole+promethazine & Qt prolongation & 2 & $(1.3)$ & 2 & (1.3) & 4 & (2) \\
\hline cefoperazone+heparin & $\begin{array}{c}\text { increase risk of } \\
\text { bleeding }\end{array}$ & 1 & $(0.7)$ & 2 & $(1.3)$ & 3 & $(1.5)$ \\
\hline metronidazole+ondansetron & Qt prolongation & 7 & $(4.7)$ & 1 & $(0.7)$ & 8 & (4) \\
\hline ondensatron+azithromicin & Qt prolongation & 1 & $(0.7)$ & & $(0.0)$ & 1 & $(0.5)$ \\
\hline ciprofloxacin+metformin & hypoglycaemia & 1 & $(0.7)$ & 9 & $(6.0)$ & 10 & $(5)$ \\
\hline aminophylline+azithromycin & $\begin{array}{l}\text { affect theophylline } \\
\text { metabolism }\end{array}$ & 1 & $(0.7)$ & & $(0.0)$ & 1 & $(0.5)$ \\
\hline gentamicin+vancomycin & $\begin{array}{l}\text { increase risk of } \\
\text { nephrotoxicity }\end{array}$ & 1 & $(0.7)$ & & $(0.0)$ & 1 & $(0.5)$ \\
\hline erthromycin+metronidazole & Qt prolongation & 1 & $(0.7)$ & & $(0.0)$ & 1 & $(0.5)$ \\
\hline \multicolumn{8}{|l|}{ moderate } \\
\hline ampicillin+pantoprazole & $\begin{array}{c}\text { Loss of ampicillin } \\
\text { efficacy }\end{array}$ & 4 & $(2.7)$ & 1 & $(0.7)$ & 5 & $(2.5)$ \\
\hline metformin+insulin & hypoglycaemia & 1 & $(0.7)$ & & $(0.0$ & 1 & $(0.5)$ \\
\hline metronidazole+diclofenac & $\begin{array}{l}\text { increase diclofenac } \\
\text { exposure }\end{array}$ & 2 & $(1.3)$ & 4 & (2.7) & 6 & (3) \\
\hline \multicolumn{8}{|l|}{ minor } \\
\hline amoxiclav+gentamycin & $\begin{array}{c}\text { loss of aminoglycoside } \\
\text { efficacy }\end{array}$ & 2 & $(1.3)$ & 3 & $(2.0)$ & 5 & $(2.5)$ \\
\hline amikacin+augmentin & $\begin{array}{c}\text { loss of aminoglycoside } \\
\text { efficacy }\end{array}$ & 1 & $(0.7)$ & & $(0.0)$ & 1 & $(0.5)$ \\
\hline agumentin+progesterone & $\begin{array}{c}\text { decrease contraceptive } \\
\text { effectiveness }\end{array}$ & 1 & $(0.7)$ & 1 & $(0.7)$ & 1 & $(0.5)$ \\
\hline
\end{tabular}

Out of 180 prescriptions the number of drugs encountered per prescription is $6 \pm 1.2$. There were a total of 110 drug interaction found out of which drug interaction with ciprofloxacin+ondansetron and ciprofloxacin+metronidazole leading to QT prolongation is highest with $11 \%$ males in both and $2 \%$ females in former and $12 \%$ females latter. In a similar study by Mishra $\mathrm{H}$ it was found that the frequency of multiple antibiotic prescriptions in the study area was consistent with other findings in which combination of ampicillin with gentamicin was the most frequent. Majority of antibiotic combinations were prescribed based on infectious disease guidelines. No potential drug interaction was reported. Most of the multiple prescriptions were considered as producing minor drug interactions. Such drug interactions have only limited clinical effects. Manifestations may include an increase in the frequency or severity of the side-effects, but generally would not require a major alteration in therapy. In the rest of the cases of multiple drug interaction, the interactions are considered unknown, but it does not mean that they have no drug interaction at all. In our study population a total of $92 \%$ prescription was seen to be having rational prescribing of antibiotic and $8 \%$ had irrational prescribing due to frequency incorrect, wrong drug prescribed which is not indicated for the disease and in some hospital policy was not followed. In a similar study by naushen $\mathrm{S}$ et al. on rational use of antibiotics it was found that Therapeutic antibiotic use was rationalized, reducing the use of therapeutic antibiotics from $97 \%$ $(\mathrm{n}=160 / 165)$ in January 2010 to $8 \%(\mathrm{n}=10 / 125)$ in December 2010. Surgical site infection rates were less than $5 \%$. Cost of antibiotics per patient decreased by $90 \%$. Decrease in the length of stay and workload on nursing staff was also observed ${ }^{2}$. In a study by Vandhana $\mathrm{AB}$ et al on prescribing pattern of antimicrobial agents in central part of India it was found that in $30 \%$ patient the antimicrobial therapy considered rational, in $59 \%$ patient therapy considered irrational while in $11 \%$ patient it is questionable. [1] 


\section{CONCLUSION}

The importance of modern therapeutic agents for diagnostic, curative and preventive purpose and their contribution to health care requires no emphasis. However, it is important to realize that every medicine is potentially hazardous.1Of these, antibiotics are one of the most common drugs prescribed in hospitals today. Inappropriate use of antibiotics is common and presents a potential hazard to patients with increasing bacterial resistance and increased hospital costs. Antibiotic resistance, a well-known phenomenon in nature 3 gets amplified due to human misuse and neglect. This has thus become a serious public health concern with economic and social implications globally. Antibiotic therapy eradicates not only pathogenic organisms but also the protective normal flora. This so called 'selective pressure' results in colonization with bacteria that are resistant to the original therapy and can also lead to emergence of superbugs which are highly resistant strains and also can lead to the use of alternative drugs with lesser known safety profiles. In appropriate use of antibiotics is detected due to lack of culture sensitivity test which has to make mandatory in the hospital before antibiotic prescription.

Less cost effective antibiotic treatment should be prescribed. Polypharmacy was seen in a large extent were patients were put on 4-5 antibiotics which has to be avoided by using broad spectrum antibiotics and fixed dose antibiotics suitably. The drug interactions with antibiotics should be also minimized.

\section{REFRENCES}

[1]. Badar V A, Navale S B. Study of Prescribing Pattern of Antimicrobial Agents in Medicine Intensive Care Unit of a Teaching Hospital in Central India. JAPI April 2012; VOL 60:20-23

[2]. Blondeau JM. Appropriate antibiotic use - past lessons provide future directions. In: Low DE, editor. Appropriate Antibiotic Use. Worcester: The Royal Society of Medicine Press Limited; 2000. pp. 1-10.

[3]. Drug Industry Employer Union. Drugs in Turkey. Istanbul; 2000.

[4]. Emori TG, Gaynes RP. An overview of nosocomial infections, including the role of the microbiology laboratory. Clin Microbiol Rev 1993;6:428-42.

[5]. Haley RW, Schaberg DR, Crossley KB, Von Allmen SD, Mc Gowan JE Jr. Extracharges and prolongation of stay attributable to nosocomial infections: aprospective interhospital comparison. Am J Med 1981;70:51-8.

[6]. K.D.Tripathi, Essentials of medical pharmacology, Chapter no: 49, page no: 667

[7]. Kasim Mahmoud Jumaa, Saad Abdel Rahman Hussien, Ali Mousa Jaffer, Ali Saqban Abdel Alaziz, Rasha Ahmed Abdel Latif, Antibiotic Prescription Style in Surgery Department in Baquba Teaching Hospital, page no: 152.

[8]. Kunin CM, Lipton HL, Tupasi T, Sacks T, Schecker WE, social,behavioural and practical factors affecting antibiotic use worldwide. Report of task force 4. Rev Infect Dis 1987; 9 (suppl 1): S270- S85.

[9]. Ledger WJ, Prophylactic antibiotics in obstetrics and Gynaeocology. A current asset, a future liability? Expert Rev Anti Infect Ther 2006; 4: 957-64.

[10]. Lim VKE, cheongYm, Suleiman AB. Pattern of antibiotic usage in hospital in Malaysia. Singapore Med J 1993; 34: 525-8.

[11]. Mc Donald LC, Yu HT, Yin HC, Hsiung AC, Ho M. Use and abuse of surgical antibiotic prophylaxis in hospital in Taiwan. J Formos Med Assoc 2001; 100: 5-13.

[12]. Nastaran Talank, Shibi Mary Thomas, Dr.Raju Koneri, Ali Arab. A prospective study on antibiotic utilization in surgery and pediatric department, case study Baptist hospital, Bangalore, Karnataka. Int. J. $\begin{array}{lllll}\text { Adv. } & \text { Multidiscip. } & \text { Res. } & \text { (2016). } & \text { 3(6): }\end{array}$ Polk RE, Fishman NO. Antimicrobial management: cost and resistance. In: Mandell GL, Bennett JE, Dolin R, editors. Principles and Practice of Infectious Diseases. 6th ed. Philadelphia: Churchill Livingstone Inc; 2005. pp. 611-9.

[13]. Singhal H., Kaur K, Zammit C. Wound infection. 2009. Retrieved from http://emedicine.medscape.com/article/188988- overview. TeferraAbula, Mohammed Kedir, The pattern of antibiotic usage in surgical in-patients of a teaching hospital, northwest Ethiopia, [Ethiop.J.Health Dev. 2004;18(1):35-38]

[14]. Wendy Munckhof, Infectious Diseases Physician and Clinical Microbiologist, Princess Alexandra Hospital, and Senior Lecturer in Medicine, University of Queensland, Brisbane, Antibiotics for surgical prophylaxis, (Aust Prescr 2005;28:38-40)

IOSR Journal of Pharmacy (IOSR-PHR) is UGC approved Journal with Sl. No. 5012

Mahdieh Soleimani . "Antibiotic Utilization Pattern in Surgery and Pediatric, Bhagwan Mahaveer Jain Hospital, Bangalore, India." IOSR Journal of Pharmacy 7.7 (2017): 06-10. 